\title{
Defining Natural Antibodies
}

\author{
Nichol E. Holodick ${ }^{1 *}$, Nely Rodríguez-Zhurbenko ${ }^{2}$ and Ana María Hernández ${ }^{2 *}$ \\ ${ }^{1}$ Department of Biomedical Sciences, Center for Immunobiology, Western Michigan University Homer Stryker M.D. School \\ of Medicine, Kalamazoo, MI, United States, ${ }^{2}$ Natural Antibodies Group, Tumor Immunology Division, Center of Molecular \\ Immunology, Havana, Cuba
}

\section{OPEN ACCESS}

Edited by:

Harry W. Schroeder,

University of Alabama at

Birmingham, United States

Reviewed by:

Andre M. Vale,

Federal University of Rio

de Janeiro, Brazil

Michael Zemlin,

Universitätsklinikum des

Saarlandes, Germany

*Correspondence:

Nichol E. Holodick

nichol.holodick@med.wmich.edu;

Ana María Hernández anita@cim.sld.cu

Specialty section:

This article was submitted

to B Cell Biology,

a section of the journal

Frontiers in Immunology

Received: 27 April 2017 Accepted: 10 July 2017

Published: 26 July 2017

Citation:

Holodick NE, Rodríguez-Zhurbenko N and Hernández AM (2017)

Defining Natural Antibodies.

Front. Immunol. 8:872.

doi: 10.3389/fimmu.2017.00872
The traditional definition of natural antibodies (NAbs) states that these antibodies are present prior to the body encountering cognate antigen, providing a first line of defense against infection thereby, allowing time for a specific antibody response to be mounted. The literature has a seemingly common definition of NAbs; however, as our knowledge of antibodies and $\mathrm{B}$ cells is refined, re-evaluation of the common definition of NAbs may be required. Defining NAbs becomes important as the function of NAb production is used to define $B$ cell subsets (1) and as these important molecules are shown to play numerous roles in the immune system (Figure 1). Herein, we aim to briefly summarize our current knowledge of NAbs in the context of initiating a discussion within the field of how such an important and multifaceted group of molecules should be defined.

Keywords: natural antibody, antibodies, natural antibody repertoire, B-1 cells, B cell subsets, B cells

\section{NATURAL ANTIBODY (NAb) PRODUCING CELLS}

Both murine and human NAbs have been discussed in detail since the late 1960s $(2,3)$; however, cells producing NAbs were not identified until 1983 in the murine system $(4,5)$. These cells, named B-1 cells, were originally identified by their expression of CD5 and were further characterized by surface expression of $\mathrm{IgM}^{\text {high }}$, IgD ${ }^{\text {low }}, \mathrm{CD} 19^{\text {high }}, \mathrm{B} 220^{\text {low }}, \mathrm{CD} 23^{-}$, and $\mathrm{CD}^{2} 3^{+}(6)$, which contrasts with the surface phenotype of follicular B-2 cells: CD5 $5^{-}, \mathrm{IgM}^{\text {low }}$, IgD ${ }^{\text {high }}, \mathrm{CD} 19^{+}, \mathrm{B} 220^{+}, \mathrm{CD}^{2} 3^{+}$, and $\mathrm{CD}^{-} 3^{-}$. Later, an additional population of B-1 cells was identified, which shared the characteristics of $\mathrm{CD}^{+} \mathrm{B}-1$ but lacked CD5 expression (7). These two populations of B-1 cells are termed B-1a $\left(\mathrm{CD}^{+}\right)$and B-1b $\left(\mathrm{CD}^{-}\right)$cells. B-1 cells also express CD11b; however, this expression is limited to B-1 cells residing in the body cavities and is lost upon migration to the spleen $(8,9)$. Furthermore, the B-1 cell population can be divided not only phenotypically but also functionally into natural or antigen-induced antibody secreting cells (10).

B-1 cells are found in various tissues of adult mice, which include the peritoneal cavity, pleural cavity, spleen, bone marrow, lymph nodes, and blood [reviewed in Ref. (11)]. The tissue location may influence the functional role of B-1 cells. The peritoneal and pleural cavities have been shown to be an important reservoir for B-1 cells that respond to various stimuli (12-16) and subsequently migrate to the spleen/mesenteric or mediastinal lymph nodes, respectively, where they begin to secrete antibody (17). In mice depleted of B cells, peritoneal B-1 cells have the ability to fully reconstitute natural serum immunoglobulin (Ig) M as well as B-1 cells in all tissue locations (18); yet, in normal healthy mice, peritoneal B-1a cells do not directly contribute to natural serum IgM (19). Instead, the direct sources of natural serum IgM are B-1a cells located in the spleen and bone marrow (19). It has been shown that peritoneal B-1a cells recirculate from the peritoneum to the blood in a CXCL13-dependent manner (20). Interestingly, in the absence of CXCL13, mice are devoid of peritoneal B-1 cells but still have splenic B-1 cells; yet, despite having normal levels of serum IgM these mice have significantly less natural IgM specific for phosphorylcholine (20). 


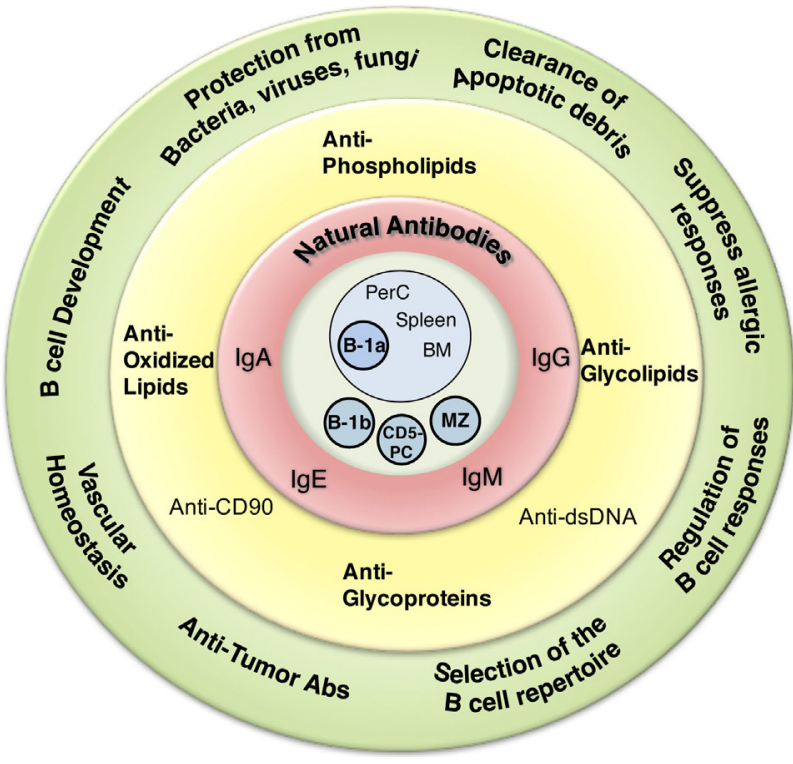

FIGURE 1 | Overview of natural antibodies' (NAbs) attributes. Graphical representation of the various NAb functions (outside green circle), epitope recognition (inside yellow circle), isotype (inside red circle), and cells shown to produce NAbs (inside blue circle).

This study suggests that it is possible for peritoneal B-1 cells to contribute to the splenic B-1 cell population and this recirculation might be particularly important for certain NAb reactivites. To date, the exact developmental relationship between the NAb secreting splenic/bone marrow B-1a cells and peritoneal B-1a cells is still unknown.

Beyond heterogeneity at different tissue sites, various subpopulations of B-1a cells have been defined based on surface marker expression. In the peritoneal cavity, B-1a subpopulations include PD-L2 (PD-L2 $\left.{ }^{+/-}\right)(21,22)$, CD25 (CD25 $\left.5^{+/-}\right)(23)$, CD73 (CD73 $\left.{ }^{\text {hi/lo }}\right)$ (24), and PC-1 (PC-1 $\left.1^{\mathrm{h} / / \mathrm{o}}\right)$. The PD-L2, CD25, and CD73 subsets showed no difference in the amount of natural IgM secretion between positive and negative subsets (21-24). Conversely, PC-1 $\mathrm{B}-1 \mathrm{a}$ cell subsets differed in the level of natural IgM secretion. PC- $1^{\text {lo }} \mathrm{B}-1 \mathrm{a}$ cells were shown to produce the large majority of natural IgM (25). PC-1 $1^{\text {hi }}$ B-1a cells produced a significantly lower level of natural IgM and contained B-1a cells producing the antiphosphatidylcholine (anti-PtC) specificity $(25,26)$. B-1a cells have also been shown to produce IL-10 in the absence of stimulation (27); however, the relationship between regulatory (B10) cells (28) and B-1a cells is still unknown. In the bone marrow, a fetalderived $\mathrm{B}$ cell subset was recently identified, which phenotypes as a plasmablast/plasma cell $\left(\mathrm{CD}^{-} \mathrm{IgM}^{+} \mathrm{IgD}^{-} \mathrm{CD} 138^{+} \mathrm{B} 220^{\mathrm{lo} /}-\right.$ $\mathrm{FSC}^{\text {hi }} \mathrm{CD}^{+} 3^{+}$) (29); it is unknown whether this population is a terminally differentiated B-1, B-2, or novel population of cells (19). In the spleen, a population of CD138 + B-1a cells is present in unimmunized mice, which rapidly respond to stimulation prior to immigration of peritoneal B-1 cells to the spleen (30). The spleen is also home to marginal zone B cells, which also produce NAbs (31); however, it has been demonstrated that greater than $90 \%$ of NAb is produced by B-1 cells (18).
Given the evidence described previously, it is clear in mice, more than one $\mathrm{B}$ cell population is responsible for NAb production and not all subsets of B-1 cells spontaneously secrete NAbs that accumulate in serum. Thus, the generalization that all B-1 cells secrete NAbs should be avoided. This point has important implications when comparing the molecular repertoire of a certain B-1 cell subset as it relates to the total natural serum IgM repertoire, which would include the molecular repertoire of numerous B-1 cell subsets from various locations (10).

Natural antibody secreting cells in humans were first identified as $\mathrm{CD}^{+}$peripheral B cells (32-35). Later, it was demonstrated that $\mathrm{CD}^{-} \mathrm{CD} 45 \mathrm{RA}^{\text {lo }}$ peripheral $\mathrm{B}$ cells could also produce natural IgM (36). Much of the early work in humans focused on characterization and comparison of polyreactive antibodies, which were shown to utilize $\mathrm{VH} 4$ more frequently than monoreactive antibodies (37). More recently, strides have been made to refine the phenotypic characterization of $\mathrm{NAb}$ producing cells in the human system by starting with functional characteristics such as natural/spontaneous antibody secretion. This approach yielded a new phenotypic definition, $\mathrm{CD} 20^{+} \mathrm{CD} 27^{+} \mathrm{CD} 43^{+} \mathrm{CD} 70^{-} \mathrm{CD} 38^{\mathrm{mod}}$, of $\mathrm{NAb}$ secreting cells, the majority of which express CD5 $(1,38)$. Nevertheless, the phenotype of antibody secreting cells in the peripheral blood of humans is still evolving. Further investigation of NAb secreting cells in the human system is needed to elucidate the specific types of cells that are capable of producing NAbs, as well as the location of these cells beyond peripheral blood.

\section{NAb REACTIVITY}

Although NAbs are known for their broad reactivity against self-antigens, some have the ability to recognize evolutionarily fixed epitopes present in foreign antigens. Whether or not $\mathrm{NAb}$ recognition of foreign structures is always the result of cross-reactivity against self-antigens is still a matter of debate. Generally, the most well-characterized epitopes to date include phospholipids, oxidized lipids, glycolipids, and glycoproteins. The best characterized B-1 cell-derived NAb binds the phospholipid phosphorylcholine and utilizes VHS107.1 (39). Phosphorylcholine is found within the bacterial cell wall of Streptococcus pneumoniae (40) and is also exposed on apoptotic cells and oxidized lipids (41-45). In normal healthy cells, phosphorylcholine is hidden within the head group of another well-characterized NAb epitope, PtC. PtC is a normal constituent of cell membranes, which is exposed upon treatment with the protease, bromelain (46-49). Early studies revealed NAb binding to red blood cells treated with bromelain were B-1 cell derived and utilized VH11 (50, 51), VH12 (52), and Q52 (53).

Antibodies that recognize glycan epitopes are also highly abundant in both mice and humans $(54,55)$. Glycan epitopes are observed on both glycoproteins and glycolipids and can be present in autologous or pathogen-associated exogenous structures. In mice, the specificities of such antibodies are thoroughly reviewed by New et al., which include alpha-1,3-glucan, $\mathrm{N}$-acetyl-D-glucosamine, and alpha-1,3-galactose epitopes (56). In humans, the best known antiglycan antibodies react with blood group antigens A and B (57), the xenoantigen Gal-alpha-1, 
3Gal-beta-1,4GlcNAc (58, 59), Forssman glycolipid antigen, and gangliosides such as the tumor-associated antigen Neu5GcGM3 (60).

\section{NAb FUNCTIONS}

Natural antibodies provide various essential functions within the immune system. The most prevalently studied function is the ability to provide protection against bacterial, viral, and fungal infections. Such protection is afforded by NAbs' epitope recognition. In particular, NAbs have been shown to provide protection against $S$. pneumoniae (61-63), sepsis (64), Borrelia hermsii (65), influenza virus (66), Listeria monocytogenes (67), vesicular stomatitis virus (67), lymphocytic choriomeningitis virus (67), Cryptococcus neoformans (68), and Pneumocystis murina (69). In addition to NAbs to the aforementioned organisms, B-1 cells produce "induced" antibody responses against S. pneumoniae (61), B. hermsii $(65,70,71)$, influenza virus $(12,66,72)$, and Francisella tularensis $(13,73)$.

Beyond protection against various infections, NAbs serve a number of other essential functions in the immune system. These functions have been reviewed extensively elsewhere (56) and include regulation of B cell development $(10,74,75)$, selection of the $\mathrm{B}$ cell repertoire $(74,76)$, regulation of $\mathrm{B}$ cell responses (77), clearance of apoptotic debris (45), vascular homeostasis/ protection against atherosclerosis (78-81), allergic suppression $(82,83)$, and protection from cancer $(84,85)$ (Figure 1). Despite this broad range of identified NAb functions, the role of NAbs in the immune system continues to expand.

\section{NAb CHARACTERISTICS}

In mice, typical characteristics of NAbs include germline-like nucleotide structure, repertoire skewing, IgM, IgA, or IgE (86) isotype, and T cell independence. Classically, NAbs are defined as being germline like as evidenced by these antibodies lacking non-templated nucleotides ( $\mathrm{N}$-additions) and having little to no somatic hypermutation $(39,87,88)$. Antigen receptor diversity is increased during VDJ recombination when the enzyme TdT is present, which adds $\mathrm{N}$-additions to the V-D and D-J junctions (89). Such germline characteristics have been shown to be essential in NAbs' ability to protect against infection. The prototypical B-1a anti-phosphorylcholine antibody, T15, has no $\mathrm{N}$-addition $(90,91)$. In mice with forced expression of TdT, all anti-PC antibodies generated after vaccination with heat killed S. pneumoniae contain N-additions; however, these antiphosphorylcholine antibodies containing $\mathrm{N}$-additions were shown to provide no protection against $S$. pneumoniae infection (92). This study highlights the importance of germline structure in the protection provided by evolutionarily conserved NAb. In addition, NAbs derived from murine B-1a cells have a restricted repertoire. On average $5-15 \%$ of peritoneal B-1a cells recognize PtC and utilize VH11 and VH12 (93).

Other studies have shown that these "classical" characteristics of NAbs do not always apply. For instance, B-1a cells from 6- to 24-month-old mice produce Igs with significantly more
$\mathrm{N}$-additions $(94,95)$. Furthermore, it was demonstrated that B-1a cells accumulate somatic hypermutations with increasing age, which is AID dependent (96). In this same study, isotype switching was also increased in B-1a cells with age (96). Nonetheless, throughout the decades of NAb investigation, IgG and IgA have been shown to be present within the NAb pool (97-99); however, natural IgG and IgA levels decrease significantly in germ-free mice, whereas IgM levels remain unaffected (100). This suggests the amount of natural serum IgG and IgA are dependent upon exogenous antigen stimulation, whereas the level of natural serum IgM is not.

In humans, studying NAbs in the absence of antigen exposure is a challenge; however, studies performed during early human life provide a period of limited exogenous antigen exposure in the presence of undistributed, strictly controlled intrauterine antigen milieu (101). It was demonstrated that inside the fetal B cell population at 12-14 weeks of human gestation, only $\operatorname{IgM}$ and $\operatorname{IgD}$ transcripts were detected (101). Yet, after 26 weeks of gestation, B cell clones encoding IgG start to appear in a frequency similar to a frequency observed in healthy infants, which suggests IgM is not the only isotype present in the prenatal repertoire of human B cells. Furthermore, somatic hypermutations occur during human fetal B cell development even in a $\mathrm{T}$ cell-independent fashion (101). As described in mice, early human NAbs are also diverse in isotype and structure.

Non-templated nucleotides (junctional diversity) are also an important mechanism of generating Ig structural diversity, which along with combinatorial diversity and somatic mutation results in numerous Ig specificities (102-104). In mice, natural B-1a cell-derived IgM is characterized by a low number of $\mathrm{N}$-additions (105). Interestingly, TdT expression is restricted to adult life in mice (89), which is after the majority of fetal derived B-1a cell development has occurred $(105,106)$. Therefore, in mice, fetal-derived B-1a cells lack $\mathrm{N}$-additions (106), whereas adult bone marrow-derived B-1a cells display a high level of $\mathrm{N}$-additions $(95,107-109)$. In contrast, TdT is expressed during both fetal and adult life in humans, and as a result, both fetal and adult derived human $\mathrm{B}$ cells express Ig with numerous $\mathrm{N}$-additions (110). Yet, it has been shown human and mouse fetal sequences share both similarities and differences in their repertories (111). For example, even though TdT is present throughout early human life, it has been demonstrated that the number of $\mathrm{N}$-additions/CDR-H3 length in $B$ cells from preterm and term infants are shorter than that of adults (112).

\section{DEFINING NAbs}

As one reads through the body of NAb literature from the early 1960 s to the present day, it becomes increasingly difficult to find a common concrete definition. The most frequently used definition describes NAbs as preimmune antibodies generated in the absence of exogenous antigenic stimulation, which are non-specific, broadly cross-reactive, low affinity, germlinelike antibodies. As summarized in Figure 1, NAbs have many attributes, although NAbs cannot be defined by several of these 
characteristics. Furthermore, NAbs cannot be defined based on a single B cell subset or location. Different subsets of B cells in different locations are capable of secreting NAbs. Neither a specific isotype nor a specific function can define NAbs. Therefore, the characteristics left to define NAbs include how they are generated (presence or absence of endogenous and/or exogenous antigen) and their structural composition (germlinelike or diverse).

In terms of specific reactivity to exogenous antigens, studies have indicated that B-1a cells in the peritoneal cavity serve as a long-term reservoir of "natural" antibody-producing cells after first exposure to the antigen (17). However, if these B-1 cells have previously seen their cognate antigen it might be more appropriate to term these as memory B-1 cells. In fact, some subsets of peritoneal B-1a cells share similarities to memory B cells such as PD-L2 and CD73 expression $(21,24)$. Thus, it has been suggested that within the B-1 cell population, those residing in the bone marrow and the spleen are the true NAb-secreting cells (17), whereas body cavity B-1 cells constitute a population of responder (memory type) lymphocytes, which after stimulation migrate and differentiate to IgM-secreting cells. As such, it is possible body cavity B-1 cells should not be considered NAb secretors since intentional stimulation is required to upregulate the secreting process.

Other studies indicate exogenous antigens are required for selection of the overall B cell repertoire (76). In addition, altering antigenic exposure during neonatal life has been shown to significantly change the repertoire of adult B cells (82). B-1a cells are generated mainly during the fetal/neonatal period; therefore, any antigen exposure during neonatal life would be expected to significantly influence the development of B-1a cell-derived NAbs. Interestingly, it has been suggested that the neonatal period is subject to increased intestinal permeability and this access point for antigen exposure could direct the development of NAbs (56). Nonetheless, no significant difference was observed between the B-1a cell derived IgM repertoire in germfree mice when compared with specific pathogen-free mice $(96,98,113,114)$. In adult humans, the issue of antigen exposure is more of a problem as the antigenic exposure of humans cannot be controlled; therefore, studying a pre-immune repertoire is nearly impossible.

Schroeder and colleagues demonstrated the importance of both endogenous self-antigens and germline structure of antibodies in shaping the NAb repertoire. They showed the ability of the T15 NAb to clear endogenous antigen (oxidized lowdensity lipoprotein) is only dependent upon selection driven by self-antigens regardless of germline antibody structure, whereas the effectiveness of T15 to protect against exogenous antigen (phosphorylcholine/S. pneumoniae) is dependent upon both germline conservation and selection by self-antigen (115, 116). This is in line with studies by Kearney et al. demonstrating the influence of exogenous antigen upon the effectiveness of anti-phosphorylcholine antibody against $S$. pneumonia versus allergy (82). Together, these studies demonstrate how endogenous antigen, exogenous antigen, and germline composition create and alter the NAb repertoire.

Overall, these NAb studies call into question how NAbs can/ should be accurately defined. Recently, this point has been plainly
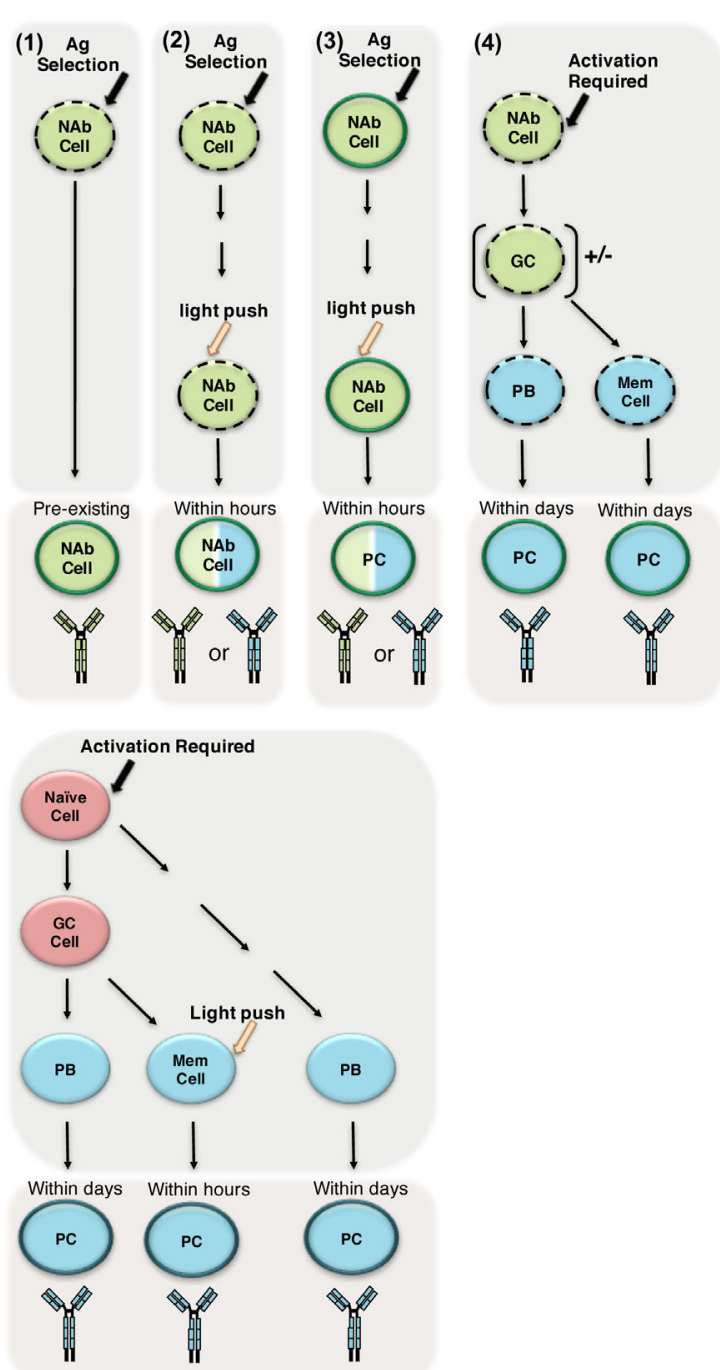

FIGURE 2 | Determining how to define natural antibodies (NAbs). (1) Most frequently used definition of NAbs: preimmune antibodies generated in the absence of exogenous antigenic stimulation, which are broadly reactive, low affinity, germline-like antibodies selected in the presence of endogenous antigen (depicted in green). These antibodies are pre-existing/always present in the serum. The dotted outline represents the intrinsic properties the cell might have (e.g., increased levels of IgM and/or CD86/CD80, lower activation threshold). The dark outline indicates the cell is secreting lg. (2-4) In panels $2-4$, we suggest possible antigenic experiences of NAbs; however, further investigation is required to determine whether antibodies produced after such antigenic experiences are the same as preimmune, pre-existing NAbs in terms of germline structure and/or repertoire. (2) Here, we suggest a NAb producing cell may require an extra antigen experience (light push ${ }^{(1)}$ ) to start immediately (within hours) secreting. This antigen experience contrasts the strong activation required for naive $\mathrm{B}-2$ cells (depicted in red) to differentiate into plasma cells (PC), which results in highly specific non-germline antibody (depicted in blue). However, it is unknown what affect this light push might have upon the antibody produced by the NAb producing cell (this is depicted by giving the cell both blue and green antibody colors). (3) We suggest a NAb producing cell that is already secreting NAbs experiences antigen, which induces differentiation into a plasma cell (PC). Again, it is unknown what affect this differentiation might have upon the antibody produced (this is depicted by giving the cell both blue and green antibody colors). (4) Finally, we depict NAb producing cells experiencing strong/specific activation and subsequently following the traditional pathway leading to memory and plasma cell differentiation. 
discussed in two separate reviews. The first by Baumgarth et al. (17), suggests an explicit definition: "we suggest the term natural IgM production be restricted to the truly antigenindependent elaboration of IgM in the spleen and bone marrow and not be extended to antigen-induced responses by B-1 cells." The second by New et al. (56) states: "Thus, the generalization often made that the NAb repertoire develops independently of exogenous is not universal for all NAb specificities, and further research focusing on the factors contributing to the development and the composition of the NAb repertoire is warranted." Herein, we suggest that these seemingly separate points of view can find common ground with further investigation.

It is clear a NAb repertoire can be created in the absence of exogenous antigens and/or germinal center maturation, and perhaps this is the definition of NAbs in its purest form. Yet, it has also been demonstrated that NAbs are affected by the presence of exogenous antigen, which is encountered in normal functioning systems. As an attempt to incorporate the role of antigen in the NAb repertoire, we propose the following starting point for investigation. To be a NAb, two requirements are necessary: (1) the ability to exert a protective, regulatory, or other biological function and (2) pre-existing/immediately responsive antibody. In the first requirement, the biological function might be protective, regulatory, or provide a function yet to be elucidated. In the second requirement, the antibody must already be present and secreted, or the NAb encoding cell would need only

\section{REFERENCES}

1. Griffin DO, Holodick NE, Rothstein TL. Human B1 cells in umbilical cord and adult peripheral blood express the novel phenotype CD20+ CD27+ CD43+ CD70. J Exp Med (2011) 208:67-80. doi:10.1084/jem.201014992084c

2. Boyden SV. Natural antibodies and the immune response. Adv Immunol (1966) 5:1-28. doi:10.1016/S0065-2776(08)60271-0

3. Michael JG. Natural antibodies. Curr Top Microbiol Immunol (1969) 48:43-62.

4. Hayakawa K, Hardy RR, Parks DR, Herzenberg LA. The "Ly-1 B" cell subpopulation in normal immunodefective, and autoimmune mice. J Exp Med (1983) 157:202-18. doi:10.1084/jem.157.1.202

5. Hayakawa K, Hardy RR, Honda M, Herzenberg LA, Steinberg AD, Herzenberg LA. Ly-1 B cells: functionally distinct lymphocytes that secrete IgM autoantibodies. Proc Natl Acad Sci U S A (1984) 81:2494-8. doi:10.1073/ pnas.81.8.2494

6. Baumgarth N. B-cell immunophenotyping. Methods Cell Biol (2004) 75:643-62. doi:10.1016/S0091-679X(04)75027-X

7. Kantor AB, Stall AM, Adams S, Herzenberg LA, Herzenberg LA. Differential development of progenitor activity for three B-cell lineages. Proc Natl Acad Sci U S A (1992) 89:3320-4. doi:10.1073/pnas.89.8.3320

8. Ghosn EE, Yang Y, Tung J, Herzenberg LA, Herzenberg LA. CD11b expression distinguishes sequential stages of peritoneal B-1 development. Proc Natl Acad Sci U S A (2008) 105:5195-200. doi:10.1073/pnas.0712350105

9. Hastings WD, Gurdak SM, Tumang JR, Rothstein TL. CD5+/Mac-1peritoneal B cells: a novel B cell subset that exhibits characteristics of B-1 cells. Immunol Lett (2006) 105:90-6. doi:10.1016/j.imlet.2006.01.002

10. Baumgarth N. B-1 cell heterogeneity and the regulation of natural and antigen-induced IgM production. Front Immunol (2016) 7:324. doi:10.3389/ fimmu.2016.00324

11. Baumgarth $\mathrm{N}$. The double life of a B-1 cell: self-reactivity selects for protective effector functions. Nat Rev Immunol (2011) 11:34-46. doi:10.1038/nri2901

12. Choi YS, Baumgarth N. Dual role for B-1a cells in immunity to influenza virus infection. J Exp Med (2008) 205:3053-64. doi:10.1084/jem.20080979

13. Cole LE, Yang Y, Elkins KL, Fernandez ET, Qureshi N, Shlomchik MJ, et al. Antigen-specific B-la antibodies induced by Francisella tularensis LPS a light push ${ }^{1}$ for the NAb to be secreted. ${ }^{2}$ The role of antigen comes into play when considering the light push that some NAb secreting cells might need to immediately produce antibody. Furthermore, the ability of the NAb encoding cell to respond to the light push would be dependent upon its intrinsic properties such as status of surface phenotype or activation threshold. Further experimentation is required to determine whether the $\mathrm{NAb}$ produced by NAb secreting cells needing antigen exposure to immediately produce antibody differs from antibodies produced by other cells capable of immediate production of antibody (i.e., memory cells) (Figure 2). It is these authors perspective, as a field studying this clearly essential part of the immune system, we need to further investigate all contexts in which NAbs are produced and regulated (Figure 2).

\section{AUTHOR CONTRIBUTIONS}

All authors contributed to the writing and development of the perspective put forth. All authors worked together to edit and revise the manuscript.

${ }^{1}$ We are suggesting a light push to mean exposure to antigen or other stimuli leading to a differentiation pathway operating outside of the strong stimuli provided by the germinal center environment and thus, different from the naive B-2 cell requirement for stimulation.

${ }^{2}$ The subset of NAb-producing cells needing a light push might be poised to secrete but are not detected as such by the methods currently available.

provide long-term protection against F. tularensis LVS challenge. Proc Natl Acad Sci U S A (2009) 106:4343-8. doi:10.1073/pnas.0813411106

14. Kawahara T, Ohdan H, Zhao G, Yang YG, Sykes M. Peritoneal cavity B cells are precursors of splenic IgM natural antibody-producing cells. J Immunol (2003) 171:5406-14. doi:10.4049/jimmunol.171.10.5406

15. Watanabe N, Ikuta K, Fagarasan S, Yazumi S, Chiba T, Honjo T. Migration and differentiation of autoreactive B-1 cells induced by activated gamma/ delta $\mathrm{T}$ cells in antierythrocyte immunoglobulin transgenic mice. J Exp Med (2000) 192:1577-86. doi:10.1084/jem.192.11.1577

16. Waffarn EE, Hastey CJ, Dixit N, Soo Choi Y, Cherry S, Kalinke U, et al. Infection-induced type I interferons activate CD11b on B-1 cells for subsequent lymph node accumulation. Nat Commun (2015) 6:8991. doi:10.1038/ ncomms 9991

17. Baumgarth N, Waffarn EE, Nguyen TT. Natural and induced B-1 cell immunity to infections raises questions of nature versus nurture. Ann N Y Acad Sci (2015) 1362:188-99. doi:10.1111/nyas.12804

18. Lalor PA, Herzenberg LA, Adams S, Stall AM. Feedback regulation of murine Ly-1 B cell development. Eur J Immunol (1989) 19:507-13. doi:10.1002/eji.1830190315

19. Savage HP, Baumgarth N. Characteristics of natural antibody-secreting cells. Ann N Y Acad Sci (2015) 1362:132-42. doi:10.1111/nyas.12799

20. Ansel KM, Harris RB, Cyster JG. CXCL13 is required for B1 cell homing, natural antibody production, and body cavity immunity. Immunity (2002) 16:67-76. doi:10.1016/S1074-7613(01)00257-6

21. Zhong X, Tumang JR, Gao W, Bai C, Rothstein TL. PD-L2 expression extends beyond dendritic cells/macrophages to B1 cells enriched for $\mathrm{V}(\mathrm{H}) 11 / \mathrm{V}(\mathrm{H}) 12$ and phosphatidylcholine binding. Eur JImmunol (2007) 37:2405-10. doi:10.1002/eji.200737461

22. Zhong X, Lau S, Bai C, Degauque N, Holodick NE, Steven SJ, et al. A novel subpopulation of B-1 cells is enriched with autoreactivity in normal and lupus-prone mice. Arthritis Rheum (2009) 60:3734-43. doi:10.1002/ art. 25015

23. Tumang JR, Holodick NE, Vizconde TC, Kaku H, Frances R, Rothstein TL. A CD25(-) positive population of activated B1 cells expresses LIFR and responds to LIF. Front Immunol (2011) 2:6. doi:10.3389/fimmu.2011.00006 
24. Kaku H, Cheng KF, Al-Abed Y, Rothstein TL. A novel mechanism of B cell-mediated immune suppression through CD73 expression and adenosine production. J Immunol (2014) 193:5904-13. doi:10.4049/jimmunol. 1400336

25. Wang H, Shin DM, Abbasi S, Jain S, Kovalchuk AL, Beaty N, et al. Expression of plasma cell alloantigen 1 defines layered development of B-1a B-cell subsets with distinct innate-like functions. Proc Natl Acad Sci U S A (2012) 109:20077-82. doi:10.1073/pnas.1212428109

26. Wang H, Lin JX, Li P, Skinner J, Leonard WJ, Morse HC III. New insights into heterogeneity of peritoneal B-1a cells. Ann N Y Acad Sci (2015) 1362:68-76. doi:10.1111/nyas.12791

27. O'Garra A, Chang R, Go N, Hastings R, Haughton G, Howard M. Ly-1 B (B-1) cells are the main source of B cell-derived interleukin 10. Eur J Immunol (1992) 22:711-7. doi:10.1002/eji.1830220314

28. Bouaziz JD, Yanaba K, Tedder TF. Regulatory B cells as inhibitors of immune responses and inflammation. Immunol Rev (2008) 224:201-14. doi:10.1111/j.1600-065X.2008.00661.x

29. Reynolds AE, Kuraoka M, Kelsoe G. Natural IgM is produced by CD5plasma cells that occupy a distinct survival niche in bone marrow. JImmunol (2015) 194:231-42. doi:10.4049/jimmunol.1401203

30. Yang Y, Tung JW, Ghosn EE, Herzenberg LA, Herzenberg LA. Division and differentiation of natural antibody-producing cells in mouse spleen. Proc Natl Acad Sci U S A (2007) 104:4542-6. doi:10.1073/pnas.0700001104

31. Ichikawa D, Asano M, Shinton SA, Brill-Dashoff J, Formica AM, Velcich A, et al. Natural anti-intestinal goblet cell autoantibody production from marginal zone B cells. J Immunol (2015) 194:606-14. doi:10.4049/jimmunol. 1402383

32. Casali P, Notkins AL. CD5+ B lymphocytes, polyreactive antibodies and the human B-cell repertoire. Immunol Today (1989) 10:364-8. doi:10.1016/ 0167-5699(89)90268-5

33. Antin JH, Emerson SG, Martin P, Gadol N, Ault KA. Leu-1+ (CD5+) B cells. A major lymphoid subpopulation in human fetal spleen: phenotypic and functional studies. J Immunol (1986) 136:505-10.

34. Kipps TJ, Fong S, Tomhave E, Chen PP, Goldfien RD, Carson DA. High-frequency expression of a conserved kappa light-chain variable-region gene in chronic lymphocytic leukemia. Proc Natl Acad Sci U S A (1987) 84:2916-20. doi:10.1073/pnas.84.9.2916

35. Casali P, Burastero SE, Nakamura M, Inghirami G, Notkins AL. Human lymphocytes making rheumatoid factor and antibody to ssDNA belong to Leu-1+ B-cell subset. Science (1987) 236:77-81. doi:10.1126/science. 3105056

36. Kasaian MT, Ikematsu H, Casali P. Identification and analysis of a novel human surface CD5- B lymphocyte subset producing natural antibodies. J Immunol (1992) 148:2690-702.

37. Casali P, Schettino EW. Structure and function of natural antibodies. Curr Top Microbiol Immunol (1996) 210:167-79.

38. Quach TD, Rodriguez-Zhurbenko N, Hopkins TJ, Guo X, Hernandez AM, Li W, et al. Distinctions among circulating antibody-secreting cell populations, including B-1 cells, in human adult peripheral blood. J Immunol (2016) 196:1060-9. doi:10.4049/jimmunol.1501843

39. Feeney AJ. Predominance of the prototypic T15 anti-phosphorylcholine junctional sequence in neonatal pre-B cells. J Immunol (1991) 147:4343-50.

40. Brundish DE, Baddiley J. Pneumococcal C-substance, a ribitol teichoic acid containing choline phosphate. Biochem J (1968) 110:573-82. doi:10.1042/ bj1 100573

41. Shaw PX, Horkko S, Chang MK, Curtiss LK, Palinski W, Silverman GJ, et al. Natural antibodies with the T15 idiotype may act in atherosclerosis, apoptotic clearance, and protective immunity. JClin Invest (2000) 105: 1731-40. doi:10.1172/JCI8472

42. Binder CJ, Horkko S, Dewan A, Chang MK, Kieu EP, Goodyear CS, et al. Pneumococcal vaccination decreases atherosclerotic lesion formation: molecular mimicry between Streptococcus pneumoniae and oxidized LDL. Nat Med (2003) 9:736-43. doi:10.1038/nm876

43. Chen Y, Park YB, Patel E, Silverman GJ. IgM antibodies to apoptosisassociated determinants recruit $\mathrm{Clq}$ and enhance dendritic cell phagocytosis of apoptotic cells. J Immunol (2009) 182:6031-43. doi:10.4049/ jimmunol.0804191

44. Chou MY, Fogelstrand L, Hartvigsen K, Hansen LF, Woelkers D, Shaw PX, et al. Oxidation-specific epitopes are dominant targets of innate natural antibodies in mice and humans. J Clin Invest (2009) 119:1335-49. doi:10.1172/ JCI36800

45. Gronwall C, Vas J, Silverman GJ. Protective roles of natural IgM antibodies. Front Immunol (2012) 3:66. doi:10.3389/fimmu.2012.00066

46. Cunningham AJ. Large numbers of cells in normal mice produce antibody components of isologous erythrocytes. Nature (1974) 252:749-51. doi: $10.1038 / 252749 \mathrm{a} 0$

47. Lord EM, Dutton RW. The properties of plaque-forming cells from autoimmune and normal strains of mice with specificity for autologous erythrocyte antigens. J Immunol (1975) 115:1199-205.

48. Cox KO, Hardy SJ. Autoantibodies against mouse bromelain-modified RBC are specifically inhibited by a common membrane phospholipid, phosphatidylcholine. Immunology (1985) 55:263-9.

49. Mercolino TJ, Arnold LW, Haughton G. Phosphatidyl choline is recognized by a series of Ly-1+ murine B cell lymphomas specific for erythrocyte membranes. J Exp Med (1986) 163:155-65. doi:10.1084/jem.163.1.155

50. Reininger L, Ollier P, Poncet P, Kaushik A, Jaton JC. Novel V genes encode virtually identical variable regions of six murine monoclonal antibromelain-treated red blood cell autoantibodies. J Immunol (1987) 138: 316-23.

51. Hardy RR, Carmack CE, Shinton SA, Riblet RJ, Hayakawa K. A single VH gene is utilized predominantly in anti-BrMRBC hybridomas derived from purified Ly-1 B cells. Definition of the VH11 family. J Immunol (1989) 142:3643-51.

52. Pennell CA, Sheehan KM, Brodeur PH, Clarke SH. Organization and expression of VH gene families preferentially expressed by Ly-1+ (CD5) B cells. Eur J Immunol (1989) 19:2115-21. doi:10.1002/eji.1830191122

53. Seidl KJ, MacKenzie JD, Wang D, Kantor AB, Kabat EA, Herzenberg LA, et al. Frequent occurrence of identical heavy and light chain Ig rearrangements. Int Immunol (1997) 9:689-702. doi:10.1093/intimm/9.5.689

54. Dai H, Zhang Y, Lv P, Gao XM. A study on the glycan specificity of natural antibody repertoires in rodents. Cell Mol Immunol (2009) 6:453-9. doi:10.1038/cmi.2009.57

55. Huflejt ME, Vuskovic M, Vasiliu D, Xu H, Obukhova P, Shilova N, et al. Anti-carbohydrate antibodies of normal sera: findings, surprises and challenges. Mol Immunol (2009) 46:3037-49. doi:10.1016/j.molimm. 2009.06.010

56. New JS, King RG, Kearney JF. Manipulation of the glycan-specific natural antibody repertoire for immunotherapy. Immunol Rev (2016) 270:32-50. doi:10.1111/imr.12397

57. Shilova N, Huflejt ME, Vuskovic M, Obukhova P, Navakouski M, Khasbiullina N, et al. Natural antibodies against sialoglycans. Top Curr Chem (2015) 366:169-81. doi:10.1007/128_2013_469

58. McKane W, Lee J, Preston R, Hacking A, Simpson P, Lynds S, et al. Polymorphism in the human anti-pig natural antibody repertoire: implications for antigen-specific immunoadsorption. Transplantation (1998) 66:626-33. doi:10.1097/00007890-199809150-00014

59. Galili U. Anti-Gal: an abundant human natural antibody of multiple pathogeneses and clinical benefits. Immunology (2013) 140:1-11. doi:10.1111/ imm. 12110

60. Rodriguez-Zhurbenko N, Martinez D, Blanco R, Rondon T, Grinan T, Hernandez AM. Human antibodies reactive to NeuGcGM3 ganglioside have cytotoxic antitumor properties. Eur JImmunol (2013) 43:826-37. doi:10.1002/eji.201242693

61. Haas KM, Poe JC, Steeber DA, Tedder TF. B-1a and B-1b cells exhibit distinct developmental requirements and have unique functional roles in innate and adaptive immunity to S. pneumoniae. Immunity (2005) 23:7-18. doi:10.1016/j.immuni.2005.04.011

62. Briles DE, Nahm M, Schroer K, Davie J, Baker P, Kearney J, et al. Antiphosphocholine antibodies found in normal mouse serum are protective against intravenous infection with type 3 Streptococcus pneumoniae. J Exp Med (1981) 153:694-705. doi:10.1084/jem.153.3.694

63. Mi QS, Zhou L, Schulze DH, Fischer RT, Lustig A, Rezanka LJ, et al. Highly reduced protection against Streptococcus pneumoniae after deletion of a single heavy chain gene in mouse. Proc Natl Acad Sci U S A (2000) 97:6031-6. doi:10.1073/pnas.110039497

64. Boes M, Prodeus AP, Schmidt T, Carroll MC, Chen J. A critical role of natural immunoglobulin $\mathrm{M}$ in immediate defense against systemic bacterial infection. J Exp Med (1998) 188:2381-6. doi:10.1084/jem.188.12.2381 
65. Alugupalli KR, Gerstein RM, Chen J, Szomolanyi-Tsuda E, Woodland RT, Leong JM. The resolution of relapsing fever borreliosis requires IgM and is concurrent with expansion of B1b lymphocytes. JImmunol (2003) 170:3819-27. doi:10.4049/jimmunol.170.7.3819

66. Baumgarth N, Herman OC, Jager GC, Brown L, Herzenberg LA, Herzenberg LA. Innate and acquired humoral immunities to influenza virus are mediated by distinct arms of the immune system. Proc Natl Acad Sci U S A (1999) 96:2250-5. doi:10.1073/pnas.96.5.2250

67. Ochsenbein AF, Fehr T, Lutz C, Suter M, Brombacher F, Hengartner H, et al. Control of early viral and bacterial distribution and disease by natural antibodies. Science (1999) 286:2156-9. doi:10.1126/science.286. 5447.2156

68. Subramaniam KS, Datta K, Quintero E, Manix C, Marks MS, Pirofski LA. The absence of serum IgM enhances the susceptibility of mice to pulmonary challenge with Cryptococcus neoformans. J Immunol (2010) 184:5755-67. doi:10.4049/jimmunol.0901638

69. Rapaka RR, Ricks DM, Alcorn JF, Chen K, Khader SA, Zheng M, et al. Conserved natural IgM antibodies mediate innate and adaptive immunity against the opportunistic fungus Pneumocystis murina. J Exp Med (2010) 207:2907-19. doi:10.1084/jem.20100034

70. Alugupalli KR, Leong JM, Woodland RT, Muramatsu M, Honjo T, Gerstein RM. B1b lymphocytes confer $\mathrm{T}$ cell-independent long-lasting immunity. Immunity (2004) 21:379-90. doi:10.1016/j.immuni.2004.06.019

71. Colombo MJ, Alugupalli KR. Complement factor H-binding protein, a putative virulence determinant of Borrelia hermsii, is an antigenic target for protective B1b lymphocytes. J Immunol (2008) 180:4858-64. doi:10.4049/ jimmunol.180.7.4858

72. Baumgarth N, Herman OC, Jager GC, Brown LE, Herzenberg LA, Chen J. B-1 and B-2 cell-derived immunoglobulin M antibodies are nonredundant components of the protective response to influenza virus infection. J Exp Med (2000) 192:271-80. doi:10.1084/jem.192.2.271

73. Yang Y, Ghosn EE, Cole LE, Obukhanych TV, Sadate-Ngatchou P, Vogel SN, et al. Antigen-specific antibody responses in B-1a and their relationship to natural immunity. Proc Natl Acad Sci U S A (2012) 109:5382-7. doi:10.1073/pnas.1121631109

74. Nguyen TT, Elsner RA, Baumgarth N. Natural IgM prevents autoimmunity by enforcing B cell central tolerance induction. JImmunol (2015) 194:1489-502. doi:10.4049/jimmunol.1401880

75. Nguyen TT, Klasener K, Zurn C, Castillo PA, Brust-Mascher I, Imai DM, et al. The IgM receptor FcmuR limits tonic BCR signaling by regulating expression of the IgM BCR. Nat Immunol (2017) 18:321-33. doi:10.1038/ ni.3677

76. Freitas AA, Viale AC, Sundblad A, Heusser C, Coutinho A. Normal serum immunoglobulins participate in the selection of peripheral B-cell repertoires. Proc Natl Acad Sci U S A (1991) 88:5640-4. doi:10.1073/pnas.88.13.5640

77. Boes M, Esau C, Fischer MB, Schmidt T, Carroll M, Chen J. Enhanced B-1 cell development, but impaired IgG antibody responses in mice deficient in secreted IgM. J Immunol (1998) 160:4776-87.

78. Tsiantoulas D, Diehl CJ, Witztum JL, Binder CJ. B cells and humoral immunity in atherosclerosis. Circ Res (2014) 114:1743-56. doi:10.1161/ CIRCRESAHA.113.301145

79. Zhang M, Alicot EM, Chiu I, Li J, Verna N, Vorup-Jensen T, et al. Identification of the target self-antigens in reperfusion injury. J Exp Med (2006) 203:141-52. doi:10.1084/jem.20050390

80. Binder CJ, Shaw PX, Chang MK, Boullier A, Hartvigsen K, Horkko S, et al. The role of natural antibodies in atherogenesis. J Lipid Res (2005) 46:1353-63. doi:10.1194/jlr.R500005-JLR200

81. Binder CJ, Silverman GJ. Natural antibodies and the autoimmunity of atherosclerosis. Springer Semin Immunopathol (2005) 26:385-404. doi:10.1007/ s00281-004-0185-z

82. Kearney JF, Patel P, Stefanov EK, King RG. Natural antibody repertoires: development and functional role in inhibiting allergic airway disease. Annu Rev Immunol (2015) 33:475-504. doi:10.1146/annurev-immunol-032713120140

83. Patel PS, Kearney JF. Neonatal exposure to pneumococcal phosphorylcholine modulates the development of house dust mite allergy during adult life. J Immunol (2015) 194:5838-50. doi:10.4049/jimmunol.1500251

84. Vollmers HP, Brandlein S. Natural antibodies and cancer. $N$ Biotechnol (2009) 25:294-8. doi:10.1016/j.nbt.2009.03.016
85. Madi A, Bransburg-Zabary S, Maayan-Metzger A, Dar G, Ben-Jacob E, Cohen IR. Tumor-associated and disease-associated autoantibody repertoires in healthy colostrum and maternal and newborn cord sera. J Immunol (2015) 194:5272-81. doi:10.4049/jimmunol.1402771

86. McCoy KD, Harris NL, Diener P, Hatak S, Odermatt B, Hangartner L, et al. Natural IgE production in the absence of MHC class II cognate help. Immunity (2006) 24:329-39. doi:10.1016/j.immuni.2006.01.013

87. Tornberg UC, Holmberg D. B-1a, B-1b and B-2 B cells display unique VHDJH repertoires formed at different stages of ontogeny and under different selection pressures. EMBO J (1995) 14:1680-9.

88. Kantor AB, Merrill CE, Herzenberg LA, Hillson JL. An unbiased analysis of $\mathrm{V}(\mathrm{H})-\mathrm{D}-\mathrm{J}(\mathrm{H})$ sequences from B-1a, B-1b, and conventional B cells. J Immunol (1997) 158:1175-86.

89. Desiderio SV, Yancopoulos GD, Paskind M, Thomas E, Boss MA, Landau $\mathrm{N}$, et al. Insertion of $\mathrm{N}$ regions into heavy-chain genes is correlated with expression of terminal deoxytransferase in B cells. Nature (1984) 311:752-5. doi:10.1038/311752a0

90. Briles DE, Forman C, Hudak S, Claflin JL. Anti-phosphorylcholine antibodies of the T15 idiotype are optimally protective against Streptococcus pneumoniae. J Exp Med (1982) 156:1177-85. doi:10.1084/jem.156. 4.1177

91. Benedict CL, Gilfillan S, Thai TH, Kearney JF. Terminal deoxynucleotidyl transferase and repertoire development. Immunol Rev (2000) 175:150-7. doi:10.1111/j.1600-065X.2000.imr017518.x

92. Benedict CL, Kearney JF. Increased junctional diversity in fetal B cells results in a loss of protective anti-phosphorylcholine antibodies in adult mice. Immunity (1999) 10:607-17. doi:10.1016/S1074-7613(00)80060-6

93. Mercolino TJ, Arnold LW, Hawkins LA, Haughton G. Normal mouse peritoneum contains a large population of Ly-1+ (CD5) B cells that recognize phosphatidyl choline. Relationship to cells that secrete hemolytic antibody specific for autologous erythrocytes. J Exp Med (1988) 168:687-98. doi:10.1084/jem.168.2.687

94. Forster I, Gu H, Rajewsky K. Germline antibody V regions as determinants of clonal persistence and malignant growth in the B cell compartment. EMBO J (1988) 7:3693-703.

95. Holodick NE, Vizconde T, Hopkins TJ, Rothstein TL. Age-related decline in natural IgM function: diversification and selection of the B-1a cell pool with age. J Immunol (2016) 196:4348-57. doi:10.4049/jimmunol.1600073

96. Yang Y, Wang C, Yang Q, Kantor AB, Chu H, Ghosn EE, et al. Distinct mechanisms define murine $B$ cell lineage immunoglobulin heavy chain (IgH) repertoires. Elife (2015) 4:e09083. doi:10.7554/eLife.09083

97. Avrameas S. Natural autoantibodies: from 'horror autotoxicus' to 'gnothi seauton'. Immunol Today (1991) 12:154-9. doi:10.1016/0167-5699(91) 90080-D

98. Coutinho A, Kazatchkine MD, Avrameas S. Natural autoantibodies. Curr Opin Immunol (1995) 7:812-8. doi:10.1016/0952-7915(95)80053-0

99. Ikematsu H, Schettino EW, Casali P. Structure of the VH-D-JH segments of human natural polyreactive IgM and IgG antibodies. Use of germline or somatically mutated forms of commonly expressed VH genes. Ann N Y Acad Sci (1995) 764:362-9. doi:10.1111/j.1749-6632.1995.tb55848.x

100. Hooijkaas H, Benner R, Pleasants JR, Wostmann BS. Isotypes and specificities of immunoglobulins produced by germ-free mice fed chemically defined ultrafiltered "antigen-free" diet. Eur J Immunol (1984) 14:1127-30. doi:10.1002/eji.1830141212

101. Rechavi E, Lev A, Lee YN, Simon AJ, Yinon Y, Lipitz S, et al. Timely and spatially regulated maturation of $\mathrm{B}$ and $\mathrm{T}$ cell repertoire during human fetal development. Sci Transl Med (2015) 7:276ra225. doi:10.1126/scitranslmed. aaa 0072

102. Tonegawa S. Somatic generation of antibody diversity. Nature (1983) 302:575-81. doi:10.1038/302575a0

103. Alt FW, Baltimore D. Joining of immunoglobulin heavy chain gene segments: implications from a chromosome with evidence of three D-JH fusions. Proc Natl Acad Sci U S A (1982) 79:4118-22. doi:10.1073/pnas.79.13.4118

104. Xu JL, Davis MM. Diversity in the CDR3 region of $\mathrm{V}(\mathrm{H})$ is sufficient for most antibody specificities. Immunity (2000) 13:37-45. doi:10.1016/ S1074-7613(00)00006-6

105. Feeney AJ. Lack of $\mathrm{N}$ regions in fetal and neonatal mouse immunoglobulin V-D-J junctional sequences. J Exp Med (1990) 172:1377-90. doi:10.1084/ jem.172.5.1377 
106. Kantor AB. V-gene usage and N-region insertions in B-1a, B-1b and conventional B cells. Semin Immunol (1996) 8:29-35. doi:10.1006/smim. 1996.0005

107. Holodick NE, Repetny K, Zhong X, Rothstein TL. Adult BM generates CD5+ B1 cells containing abundant N-region additions. Eur J Immunol (2009) 39:2383-94. doi:10.1002/eji.200838920

108. Duber S, Hafner M, Krey M, Lienenklaus S, Roy B, Hobeika E, et al. Induction of B-cell development in adult mice reveals the ability of bone marrow to produce B-1a cells. Blood (2009) 114:4960-7. doi:10.1182/ blood-2009-04-218156

109. Esplin BL, Welner RS, Zhang Q, Borghesi LA, Kincade PW. A differentiation pathway for B1 cells in adult bone marrow. Proc Natl Acad Sci U S A (2009) 106:5773-8. doi:10.1073/pnas.0811632106

110. Asma GE, van den Bergh RL, Vossen JM. Characterization of early lymphoid precursor cells in the human fetus using monoclonal antibodies and anti-terminal deoxynucleotidyl transferase. Clin Exp Immunol (1986) 64: 356-63.

111. Schroeder HW Jr. Similarity and divergence in the development and expression of the mouse and human antibody repertoires. Dev Comp Immunol (2006) 30:119-35. doi:10.1016/j.dci.2005.06.006

112. Zemlin M, Bauer K, Hummel M, Pfeiffer S, Devers S, Zemlin C, et al. The diversity of rearranged immunoglobulin heavy chain variable region genes in peripheral blood B cells of preterm infants is restricted by short third complementarity-determining regions but not by limited gene segment usage. Blood (2001) 97:1511-3. doi:10.1182/blood.V97.5.1511
113. Hayakawa K, Asano M, Shinton SA, Gui M, Allman D, Stewart CL, et al. Positive selection of natural autoreactive B cells. Science (1999) 285:113-6. doi:10.1126/science.285.5424.113

114. Hayakawa K, Carmack CE, Hyman R, Hardy RR. Natural autoantibodies to thymocytes: origin, VH genes, fine specificities, and the role of Thy-1 glycoprotein. J Exp Med (1990) 172:869-78. doi:10.1084/jem.172.3.869

115. Vale AM, Cavazzoni CB, Nobrega A, Schroeder HW Jr. The global selfreactivity profile of the natural antibody repertoire is largely independent of germline DH sequence. Front Immunol (2016) 7:296. doi:10.3389/fimmu. 2016.00296

116. Vale AM, Kapoor P, Skibinski GA, Elgavish A, Mahmoud TI, Zemlin C, et al. The link between antibodies to OxLDL and natural protection against pneumococci depends on $\mathrm{D}(\mathrm{H})$ gene conservation. J Exp Med (2013) 210:875-90. doi:10.1084/jem.20121861

Conflict of Interest Statement: The authors declare that the research was conducted in the absence of any commercial or financial relationships that could be construed as a potential conflict of interest.

Copyright (c) 2017 Holodick, Rodríguez-Zhurbenko and Hernández. This is an open-access article distributed under the terms of the Creative Commons Attribution License (CC BY). The use, distribution or reproduction in other forums is permitted, provided the original author(s) or licensor are credited and that the original publication in this journal is cited, in accordance with accepted academic practice. No use, distribution or reproduction is permitted which does not comply with these terms. 